\title{
HOW DO THEY PERCEIVE SELECTED TECHNICAL AND DIDACTICAL TERMS TEACHERS OF PRESCHOOL EDUCATION
}

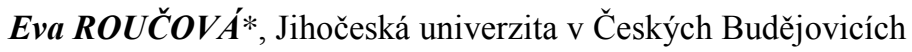

Přijato: 13. 10. 2015 / Akceptováno: 26. 10. 2015

Typ článku: Výzkumný článek

DOI: $10.5507 /$ jtie.2015.014

Abstract: The paper presents the results of a qualitative and quantitative research of selected technical and didactic concepts of kindergarten teachers. Its execution took place during the evaluation activities of the project Professional Support of Teachers of Preschool Education, the key activity of Programs of Preschool Polytechnic Education.

Key words: preschool education, technical literacy, technical education, quantitative and qualitative educational research

\section{JAK VNÍMAJÍ VYBRANÉ TECHNICKÉ A DIDAKTICKÉ POJMY UČITELKY MATEŘSKÝCH ŠKOL}

Resumé: Přispěvek prezentuje výsledky kvalitativního a kvantitativního výzkumu vybraných technických a didaktických pojmů u učitelek mateřských škol. Jeho realizace proběhla v rámci evaluačních aktivit projektu Profesni podpory pedagogů předškolního vzděláváni v klíčové aktivitě Programy předškolního polytechnického vzdělávání.

Klíčová slova: předškolni vzdělávání, technická gramotnost, technické vzdělávání, kvantitativni a kvalitativni pedagogický výzkum.

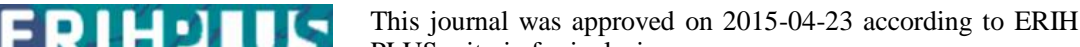
PLUS criteria for inclusion.

*Autor pro korespondenci: evro@pf.jcu.cz 


\section{1 Úvod do řešené problematiky}

Předškolní technické vzdělávání se ocitá v centru pozornosti odborné veřejnosti teprve v posledních letech. $V$ souvislosti s tím se postupně inovuje i vzdělávání učitelů mateřských škol jak v prezenční, tak kombinované formě studia a dále $\mathrm{i} v$ různých programech celoživotního vzdělávání učitelů. V současné době lze podobné trendy zaznamenat na všech pedagogických fakultách v ČR.

$\mathrm{Na}$ konci roku 2013 jsme připravovali $\mathrm{v}$ rámci studijních programů dalšího vzdělávání učitelů mateřských škol nový projekt. Při jeho koncepci jsme vycházeli z uceleného teoretického základu pro problematiku kurikulárních reforem v předškolním vzdělávání v obecné rovině autorky Šmelové, H. [1]. Dalším inspiračním odborným zdrojem koncepčních inovací předškolního technického vzdělávání byly práce především Honzíkové, J. a Sovové, P. [2].

Předpokládali jsme, že i $\mathrm{v}$ naší společnosti doposud přetrvávají některé kulturně zakotvené rodové stereotypy myšlení a jednání, které mohou komplikovat, posilována médii, vrstevníky, rodinou a jinými faktory, výslednou kvalitu vzdělávání $\mathrm{v}$ určitých oblastech, mimo jiné i v technickém vzdělávání. Tento problem nabývá na významu v tom kontextu, že převážná většina učitelů mateřských škol a tedy i našich budoucích frekventantek, jsou ženy. Weber, K. a Custer, R. [3, s. 56] konstatují, že: "učitelé techniky začínají věnovat pozornost zkušenostnímu základu studentek..... Ty často konstatují, že obsah výuky techniky, tak, jak jim byl dosud prezentován, postrádá větší důležitost pro jejich životy” (přeložila: Roučová, E. 2015). Podrobnější teoretické i praktické analýzy a souhrnná didaktická doporučení byla, pro inovovanou koncepci obsahu př̌edškolního technického vzdělávání na Pedagogické fakultě JU v Českých Budějovicích, čerpána dále především ze zdrojů $[7,8,9]$.

Výzkumná data $\mathrm{k}$ tomuto sdělení byla získávána $\mathrm{v}$ rámci Projektu OP VK Profesní podpora pedagogů předškolního vzdělávání (PF JU CZ.1.07/2.3.00/35.0001) v klíčové aktivitě Programy pro předškolní polytechnické vzdělávání.

\section{Průběh a výsledky výzkumu}

\subsection{Cíle výzkumu}

Hlavním cílem provedeného výzkumu bylo především zjistit, jak učitelky MŠ subjektivně vnímají 12 do výzkumu zařazených pojmů: Předškolní technická gramotnost, Konstrukce dětského poznání, Badatelský př́stup $\mathrm{k}$ výuce $\mathrm{v}$ MŠ, Experimenty ve výuce v MŠ, Bezpečnost a hygiena při práci v MŠ, Konstrukční činnosti v MŠ, Stavebnice Lego duplo, Prostorová tvorba v MŠ, Práce s papírem v MŠ, Práce s př́rodninami v MŠ, Lidové zvyky a řemesla v MŠ, Pokusy a pozorování v MŠ.

\section{2 Otázky výzkumu}

Výzkum byl zaměřen na celou řadu otázek, pro účely tohoto textu jsou podstatné následující problémy:

I. Jak vnímají učitelky MŠ vybrané pojmy na vstupu do výuky?

II. Jak vnímají učitelky MŠ vybrané pojmy na výstupu z výuky?

III. Došlo v průběhu výuky ke změnám ve vnímání jednotlivých pojmů?

IV. Jsou studenti schopní zkoumané pojmy vlivem výuky zrekonstruovat?

\section{3 Hypotézy výzkumu a jejich teoretické zdůvodnění}

$\mathrm{Na}$ základě teoretických analýz a pro účely tohoto článku byla stanovena a vybrána následující hlavní hypotéza: 
H1 - U zkoumaných pojmů je u učitelek MŠ mezi vnímáním na vstupu a výstupu z výuky významný rozdíl.

Kompletní a detailní hypotézy pro jednotlivé pojmy jsou uvedeny, s ohledem na možný rozsah článku a celkový vyšší počet jednotlivých hypotéz, v části 4 Testování platnosti hypotéz.

\section{Teoretické zdůvodnění hypotéz:}

Hypotézy $\mathrm{H}_{1 \mathrm{a}-\mathrm{m}}$ sloužily ke zjišsění, nakolik jsou zkoumané pojmy u respondentů plastické, schopné změny, rekonstrukce.

Podle konstruktivistické teorie lze předpokládat, že výrazný činnostní charakter a stupeň interakce studenta s učivem a použité metody výuky zkoumaných kurzů, se projeví ve změně vnímání jejích klíčových pojmů. Je ale bráno v úvahu, že mohou existovat důvody $\mathrm{k}$ předpokladu rezistence pojmů, vyplývající $\mathrm{z}$ délky výuky ( $2 \mathrm{x} 8$ hodin), věku studentů, sumy jejich školních i životních zkušeností, vyprofilovaným zájmům, zažitým mentálním vzorcům a konstrukcím i preferencím ve stylech učení. Dále zohledňujeme ještě vyskytující se zastaralý převažující charakter technického vzdělávání a učitelské zkušenosti se spiše užívanými transmisivními způsoby školní výuky, které rekonstrukci pojmů významně nepodporují.

\subsection{Výzkumný vzorek}

Výzkum proběhl $\mathrm{v}$ akademickém roce 2014/2015 a výzkumný vzorek tvořilo 262 učitelek MŠ. Výzkum se uskutečnil na Pedagogické fakultě JU v Českých Budějovicích v rámci evaluačních aktivit projektu OP VK Profesní podpora pedagogů předškolního v klíčové aktivitě Programy pro předškolní polytechnické vzdělávání. Návratnost dotazníku byla $100 \%$. Respondenti byli z Jihočeského a Západočeské kraje a z kraje Vysočina. Jednalo se pouze o ženy - učitelky, různých věkových kategorií.

\section{Výzkumné metody}

Pro výzkum, při zpracování dat a při testování platnosti hypotéz byly použity následující metody:

- Metoda teoretické analýzy odborné literatury.

- Metoda sběru a třídění dat.

- Metoda pětibodového sémantického diferenciálu pro měření individuálních psychologických významů pojmů u jednotlivých osob [5, s. 39].

- Dotazník s pětibodovou škálou sémantického diferenciálu, konstruovaný pro měření ve dvou faktorech: hodnocení a náročnosti [5, s. 55]. Pro faktor hodnocení (důležitosti) bylo ve škálách použito dvojic adjektiv dobrý - špatný, př́ijemný - nepř́ijemný, krásný - ošklivý. Pro faktor náročnosti bylo ve škálách použito dvojic adjektiv náročný - nenáročný, problémový - bezproblémový a př́sný - mírný.

- Nestandardizovaný Wilcoxonův test (pro závislé výběry) pro testování rozdílu ve středních hodnotách mezi dvěma skupinami [6, s. 119].

\section{Testování platnosti hypotéz}

H1a U pojmu Předškolní technická gramotnost je u učitelek MŠ ve vnímání pojmu na vstupu a výstupu z výuky významný rozdíl.

Nejprve jsme vždy formulovali nulovou a alternativní hypotézu k výchozí hypotéze. Vzhledem $\mathrm{k}$ omezenému rozsahu článku přesné znění nulových a alternativních hypotéz v dalším textu neuvádíme.

Pro testování platnosti všech následujících hypotéz bylo použito neparametrického Wilcoxonova testu a pomocí statistického programu STATISTICA 12 byly vypočítány 
signifikance $\mathrm{p}$, které uvádí tabulky 1 a 2 . Pro testování byla vždy zvolena hladina významnosti $\mathrm{p}=0,05$.

Na základě vypočítaných hodnoty signifikance $(\mathrm{p}<0,0023 ; 0,0358)$ lze konstatovat, že na hladině významnosti $\mathrm{p}=0,05$ odmítáme nulovou hypotézu a přijímáme hypotézu alternativní.

Konstatování: U vnímání pojmu Předškolní technická gramotnost je u učitelek MŠ ve vnímání pojmu na vstupu a výstupu z výuky ve faktorech hodnocení i náročnosti významný rozdíl. Byla tedy potvrzena platnost výchozí hypotézy $\mathrm{H}_{1 \mathrm{a}}$.

\section{Testování $\mathrm{H}_{1 \mathrm{~b}}$}

$\mathbf{H}_{1 \mathrm{~b}}$ U pojmu Konstrukce dětského poznání je u učitelek MŠ ve vnímání pojmu na vstupu a výstupu z výuky ve faktorech hodnocení i náročnosti významný rozdíl.

Na základě vypočítaných hodnoty signifikance $(\mathrm{p}<0,0075 ; 0,0021)$ lze konstatovat, že na hladině významnosti $\mathrm{p}=0,05$ odmítáme nulovou hypotézu a přijímáme hypotézu alternativní.

Konstatování: U pojmu Konstrukce dětského poznání je u učitelek MŠ ve vnímání pojmu na vstupu a výstupu z výuky ve faktorech hodnocení i náročnosti významný rozdíl. Byla tedy potvrzena platnost výchozí hypotézy $\mathrm{H}_{1 b}$.

\section{Testování $\mathbf{H}_{1 \mathrm{c}}$}

Hic $_{1}$ U pojmu Badatelský př́stup $\mathrm{k}$ výuce $\mathrm{v}$ MŠ je u učitelek MŠ ve vnímání pojmu na vstupu a výstupu $\mathrm{z}$ výuky ve faktorech hodnocení i náročnosti významný rozdíl.

Na základě vypočítaných hodnoty signifikance $(\mathrm{p}<0,0153 ; 0,0047)$ lze konstatovat, že na hladině významnosti $\mathrm{p}=0,05$ odmítáme nulovou hypotézu a přijímáme hypotézu alternativní. Byla tedy potvrzena platnost výchozí hypotézy $\mathrm{H}_{1 c}$.

Konstatování: U pojmu Badatelský př́stup $\mathrm{k}$ výuce $\mathrm{v}$ MŠ je u učitelek MŠ ve vnímání pojmu na vstupu a výstupu z výuky ve faktorech hodnocení i náročnosti významný rozdíl.

\section{Testování $\mathrm{H}_{1 \mathrm{~d}}$}

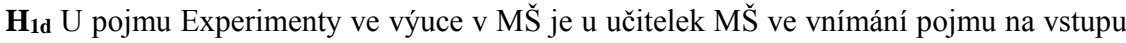
a výstupu z výuky ve faktorech hodnocení i náročnosti významný rozdíl.

Na základě vypočítaných hodnoty signifikance $(\mathrm{p}<0,0183 ; 0,0082)$ lze konstatovat, že na hladině významnosti $\mathrm{p}=0,05$ odmítáme nulovou hypotézu a přijímáme hypotézu alternativní.

Konstatování: U pojmu Experimenty ve výuce v MŠ je u učitelek MŠ ve vnímání pojmu na vstupu a výstupu $\mathrm{z}$ výuky ve faktorech hodnocení i náročnosti významný rozdíl.

Byla tedy potvrzena platnost výchozí hypotézy $\mathrm{H}_{1 d}$

\section{Testování H1e}

$\mathbf{H}_{1 \mathrm{e}} \mathrm{U}$ pojmu Bezpečnost a hygiena při práci v MŠ je u učitelek MŠ ve vnímání pojmu na vstupu a výstupu $\mathrm{z}$ výuky ve faktorech hodnocení i náročnosti významný rozdíl.

Na základě vypočítaných hodnoty signifikance $(\mathrm{p}<0,0382 ; 0,4725)$ lze konstatovat, že na hladině významnosti $\mathrm{p}=0,05$ nelze $\mathrm{u}$ obou faktorů jednoznačně rozhodnout $\mathrm{o}$ odmítnutí nulové hypotézy a přijetí hypotézy alternativní.

Konstatování: U pojmu Bezpečnost a hygiena při práci v MŠ je u učitelek MŠ ve vnímání pojmu na vstupu a výstupu z výuky ve faktoru hodnocení významný rozdíl. Ve faktoru náročnosti rozdíl významný není. Nebyla tedy zcela potvrzena platnost výchozí hypotézy $\mathrm{H}_{\mathrm{le}}$.

\section{Testování Hif}


Hif U pojmu Konstrukční činnosti v MŠ je u učitelek MŠ ve vnímání pojmu na vstupu a výstupu z výuky ve faktorech hodnocení i náročnosti významný rozdíl.

Na základě vypočítaných hodnoty signifikance $(p<0,0097 ; 0,0064)$ lze konstatovat, že na hladině významnosti $\mathrm{p}=0,05$ odmítáme nulovou hypotézu a přijímáme hypotézu alternativní.

Konstatování: U vnímání pojmu Konstrukční činnosti v MŠ je u učitelek MŠ ve vnímání pojmu na vstupu a výstupu $\mathrm{z}$ výuky ve faktorech hodnocení i náročnosti významný rozdíl. Byla tedy potvrzena platnost výchozí hypotézy $\mathrm{H}_{1 \mathrm{f}}$.

\section{Testování $\mathrm{H}_{1 \mathrm{~g}}$}

$\mathbf{H}_{1 \mathrm{~g}}$ U pojmu Stavebnice Lego duplo je u učitelek MŠ ve vnímání pojmu na vstupu a výstupu z výuky ve faktorech hodnocení i náročnosti významný rozdíl.

Na základě vypočítaných hodnoty signifikance $(\mathrm{p}<0,0796 ; 0,0035)$ lze konstatovat, že na hladině významnosti $\mathrm{p}=0,05$ nelze $\mathrm{u}$ obou faktorů jednoznačně odmítnout nulovou hypotézu a přijmout hypotézu alternativní.

Konstatování: U vnímání pojmu Stavebnice Lego duplo není u učitelek MŠ ve vnímání pojmu na vstupu a výstupu z výuky ve faktoru hodnocení významný rozdíl. Významný rozdíl byl zaznamenán pouze u faktoru hodnocení. Nebyla tedy potvrzena platnost výchozí hypotézy $\mathrm{H}_{1 \mathrm{~g}}$.

\section{Testování $\mathrm{H}_{1}$}

Hih U pojmu Prostorová tvorba v MŠ je u učitelek MŠ ve vnímání pojmu na vstupu a výstupu z výuky ve faktorech hodnocení i náročnosti významný rozdíl.

Na základě vypočítaných hodnoty signifikance $(p<0,0295 ; 0,0092)$ lze konstatovat, že na hladině významnosti $\mathrm{p}=0,05$ odmítáme nulovou hypotézu a přijímáme hypotézu alternativní.

Konstatování: U vnímání pojmu Prostorová tvorba v MŠ je u učitelek MŠ ve vnímání pojmu na vstupu a výstupu $\mathrm{z}$ výuky ve faktorech hodnocení i náročnosti významný rozdíl. Byla tedy potvrzena platnost výchozí hypotézy $\mathrm{H}_{1 \mathrm{~h}}$.

\section{Testování $\mathrm{H}_{1 \mathrm{i}}$}

$\mathbf{H}_{1 \mathrm{i}}$ U pojmu Práce s papírem v MŠ je u učitelek MŠ ve vnímání pojmu na vstupu a výstupu z výuky ve faktorech hodnocení i náročnosti významný rozdíl.

Na základě vypočítaných hodnoty signifikance $(p<0,0593 ; 0,0058)$ lze konstatovat, že na hladině významnosti $\mathrm{p}=0,05$ nelze $\mathrm{u}$ obou faktorů jednoznačně odmítnout nulovou hypotézu a přijmout hypotézu alternativní.

Konstatování: U vnímání pojmu Práce s papírem v MŠ je u učitelek MŠ ve vnímání pojmu na vstupu a výstupu $\mathrm{z}$ výuky ve faktoru náročnosti významný rozdíl, ovšem ve faktoru hodnocení rozdíl významný není. Nebyla tedy potvrzena platnost výchozí hypotézy $\mathrm{H}_{1 \mathrm{i}}$.

\section{Testování $\mathbf{H}_{\mathbf{1 j}}$}

Hij U pojmu Práce s prŕrodninami v MŠ je u učitelek MŠ ve vnímání pojmu na vstupu a výstupu z výuky ve faktorech hodnocení i náročnosti významný rozdíl.

Na základě vypočítaných hodnoty signifikance $(\mathrm{p}<0,0075 ; 0,0082)$ lze konstatovat, že na hladině významnosti $\mathrm{p}=0,05$ odmítáme nulovou hypotézu a přijímáme hypotézu alternativní.

Konstatování: U vnímání pojmu Práce s př́rodninami v MŠ je u učitelek MŠ ve vnímání pojmu na vstupu a výstupu z výuky ve faktorech hodnocení i náročnosti významný rozdíl. Byla tedy potvrzena platnost výchozí hypotézy $\mathrm{H}_{1 \mathrm{j}}$.

\section{Testování H1k}


Hik $_{1}$ U pojmu Lidové zvyky a řemesla v MŠ je u učitelek MŠ ve vnímání pojmu na vstupu a výstupu z výuky ve faktorech hodnocení i náročnosti významný rozdíl.

Na základě vypočítaných hodnoty signifikance $(\mathrm{p}<0,0284 ; 0,0074)$ lze konstatovat, že na hladině významnosti $\mathrm{p}=0,05$ odmítáme nulovou hypotézu a přijímáme hypotézu alternativní.

Konstatování: U vnímání pojmu Lidové zvyky a řemesla v MŠ je u učitelek MŠ ve vnímání pojmu na vstupu a výstupu z výuky ve faktorech hodnocení i náročnosti významný rozdíl. Byla tedy potvrzena platnost výchozí hypotézy $\mathrm{H}_{1 \mathrm{k}}$

\section{Testování $\mathrm{H}_{1 \mathrm{~m}}$}

H H $_{1 \mathrm{~m}}$ U pojmu Pokusy a pozorování v MŠ je u učitelek MŠ ve vnímání pojmu na vstupu a výstupu z výuky ve faktorech hodnocení i náročnosti významný rozdíl.

Na základě vypočítaných hodnoty signifikance $(\mathrm{p}<0,0074 ; 0,0092)$ lze konstatovat, že na hladině významnosti $\mathrm{p}=0,05$ odmítáme nulovou hypotézu a prijímáme hypotézu alternativní.

Konstatování: U vnímání pojmu Pokusy a pozorování v MŠ je u učitelek MŠ ve vnímání pojmu na vstupu a výstupu $\mathrm{z}$ výuky ve faktorech hodnocení i náročnosti významný rozdíl. Byla tedy potvrzena platnost výchozí hypotézy $\mathrm{H}_{1 \mathrm{~m}}$.

Tabulka 1: Celkové vnímání pojmů ve faktoru hodnocení

\begin{tabular}{|l|c|c|c|c|c|}
\hline \multicolumn{2}{|c|}{ Celkové vnímání zkoumaných pojmů - faktor hodnocení } \\
\cline { 2 - 7 } \multicolumn{1}{|c|}{ Pojmy } & \multicolumn{5}{c|}{ Faktor hodnocení } \\
\cline { 2 - 6 } & $\begin{array}{l}\text { průměr } \\
\text { vstup }\end{array}$ & $\begin{array}{l}\text { pořadí } \\
\text { vstup }\end{array}$ & $\begin{array}{l}\text { průměr } \\
\text { výstup }\end{array}$ & $\begin{array}{l}\text { pořadí } \\
\text { výstup }\end{array}$ & p-value \\
\hline $\begin{array}{l}\text { Předškolní technická } \\
\text { gramotnost }\end{array}$ & 2,694 & 12. & 2,36 & 12. & 0,0023 \\
\hline Konstrukce dětského poznání & 2,577 & 11. & 2,178 & 10. & 0,0075 \\
\hline $\begin{array}{l}\text { Badatelský přístup k výuce v } \\
\text { MŠ }\end{array}$ & 2,507 & 10. & 2,231 & 11. & 0,0153 \\
\hline Experimenty ve výuce v MŠ & 2,333 & 9. & 2,002 & 8. & 0,0183 \\
\hline $\begin{array}{l}\text { Bezpečnost a hygiena při práci } \\
\text { v MŠ }\end{array}$ & 2,312 & 8. & 2,16 & 9. & 0,0382 \\
\hline Konstrukční činnosti v MŠ & 2,26 & 6. & 1,825 & 4. & 0,0097 \\
\hline Stavebnice Lego duplo & 1,784 & 3. & 1,9 & 6. & 0,0796 \\
\hline Prostorová tvorba v MŠ & 2,236 & 7. & 1,914 & 7. & 0,0295 \\
\hline Práce s papírem v MŠ & 1,662 & 1. & 1,542 & 1. & 0,0593 \\
\hline Práce s př́rodninami v MŠ & 1,702 & 2. & 1,546 & 2. & 0,0075 \\
\hline Lidové zvyky a řemesla v MŠ & 1,97 & 4. & 1,711 & 3. & 0,0284 \\
\hline Pokusy a pozorování v MŠ & 2,19 & 5. & 1,85 & 5. & 0,0074 \\
\hline
\end{tabular}

Tabulka 2 :Celkové vnímání pojmů ve faktoru náročnosti 


\begin{tabular}{|l|c|c|c|c|c|}
\hline \multicolumn{5}{|c|}{ Celkové vnímání zkoumaných pojmů - faktor náročnosti } \\
\hline \multicolumn{1}{|c|}{ Pojmy } & \multicolumn{5}{c|}{ Faktor náročnosti } \\
\cline { 2 - 7 } & $\begin{array}{l}\text { průměr } \\
\text { vstup }\end{array}$ & $\begin{array}{l}\text { pořadí } \\
\text { vstup }\end{array}$ & $\begin{array}{l}\text { prúměr } \\
\text { výstup }\end{array}$ & $\begin{array}{l}\text { poŕadí } \\
\text { výstup }\end{array}$ & $\begin{array}{l}\text { p- } \\
\text { value }\end{array}$ \\
\hline $\begin{array}{l}\text { Předškolní technická } \\
\text { gramotnost }\end{array}$ & 2,668 & 12. & 2,319 & 11. & 0,0358 \\
\hline $\begin{array}{l}\text { Konstrukce dětského } \\
\text { poznání }\end{array}$ & 2,61 & 11. & 2,307 & 10. & 0,0021 \\
\hline $\begin{array}{l}\text { Badatelský př́ístup k výuce } \\
\text { v MŠ }\end{array}$ & 2,525 & 9. & 2,227 & 9. & 0,0047 \\
\hline $\begin{array}{l}\text { Experimenty ve výuce v } \\
\text { MŠS }\end{array}$ & 2,451 & 8. & 2,195 & 8. & 0,0082 \\
\hline $\begin{array}{l}\text { Bezpečnost a hygiena při } \\
\text { práci v MS̆ }\end{array}$ & 2,578 & 10. & 2,451 & 12. & 0,4725 \\
\hline Konstrukční činnosti v MŠ & 2,325 & 6. & 2,034 & 6. & 0,0064 \\
\hline Stavebnice Lego duplo & 2,113 & 3. & 1,837 & 4. & 0,0035 \\
\hline Prostorová tvorba v MŠ & 2,29 & 5. & 1,98 & 5. & 0,0092 \\
\hline Práce s papírem v MŠ & 1,916 & 1. & 1,67 & 1. & 0,0058 \\
\hline Práce s př́rodninami v MS̆ & 1,944 & 2. & 1,68 & 2. & 0,0082 \\
\hline $\begin{array}{l}\text { Lidové zvyky a řemesla v } \\
\text { MŠ }\end{array}$ & 2,26 & 4. & 1,87 & 3. & 0,0074 \\
\hline Pokusy a pozorování v MŠ & 2,38 & 7. & 2,06 & 7. & 0,0092 \\
\hline
\end{tabular}

\section{Tabulka 3: Celkové vnímání pojmů v obou faktorech}

\begin{tabular}{|l|l|l|l|l|}
\hline \multicolumn{5}{|c|}{ Celkové vnímání zkoumaných pojmů v obou faktorech } \\
\hline \multicolumn{1}{|c|}{ Pojmy } & Průměrné skóre faktoru hodnocení a náročnosti \\
\cline { 2 - 5 } & $\begin{array}{l}\text { průměr } \\
\text { vstup }\end{array}$ & $\begin{array}{l}\text { pořadí } \\
\text { vstup }\end{array}$ & $\begin{array}{l}\text { průměr } \\
\text { výstup }\end{array}$ & $\begin{array}{l}\text { pořadí } \\
\text { výstup }\end{array}$ \\
\hline $\begin{array}{l}\text { Předškolní technická } \\
\text { gramotnost }\end{array}$ & 2,681 & 12. & 2,339 & 12. \\
\hline Konstrukce dětského poznání & 2,593 & 11. & 2,242 & 10. \\
\hline $\begin{array}{l}\text { Badatelský př́stup k výuce v } \\
\text { MŠ }\end{array}$ & 2,516 & 10. & 2,229 & 9. \\
\hline Experimenty ve výuce v MŠ & 2,392 & 8. & 2,098 & 8. \\
\hline $\begin{array}{l}\text { Bezpečnost a hygiena při práci } \\
\text { v MŠ }\end{array}$ & 2,445 & 9. & 2,305 & 11. \\
\hline \multicolumn{5}{|l|}{} \\
\hline
\end{tabular}




\begin{tabular}{|l|c|c|c|c|}
\cline { 2 - 5 } \multicolumn{1}{c|}{} & \multicolumn{3}{c|}{ Průměrné skóre faktoru hodnocení a náročnosti } \\
\cline { 2 - 5 } \multicolumn{1}{c|}{$\begin{array}{l}\text { průměr } \\
\text { vstup }\end{array}$} & $\begin{array}{l}\text { pořadí } \\
\text { vstup }\end{array}$ & $\begin{array}{l}\text { průměr } \\
\text { výstup }\end{array}$ & $\begin{array}{l}\text { pořadí } \\
\text { výstup }\end{array}$ \\
\hline Konstrukční činnosti v MŠ & 2,292 & 7. & 1,929 & 5. \\
\hline Stavebnice Lego duplo & 1,948 & 3. & 1,868 & 4. \\
\hline Prostorová tvorba v MŠ & 2,263 & 5. & 1,947 & 6. \\
\hline Práce s papírem v MŠ & 1,789 & 1. & 1,606 & 1. \\
\hline Práce s př́rodninami v MŠ & 1,823 & 2. & 1,613 & 2. \\
\hline Lidové zvyky a řemesla v MŠ & 2,115 & 4. & 1,79 & 3. \\
\hline Pokusy a pozorování v MŠ & 2,285 & 6. & 1,955 & 7. \\
\hline
\end{tabular}

Graf 1: Celkové průměrné vnímání pojmů u učitelek MŠ

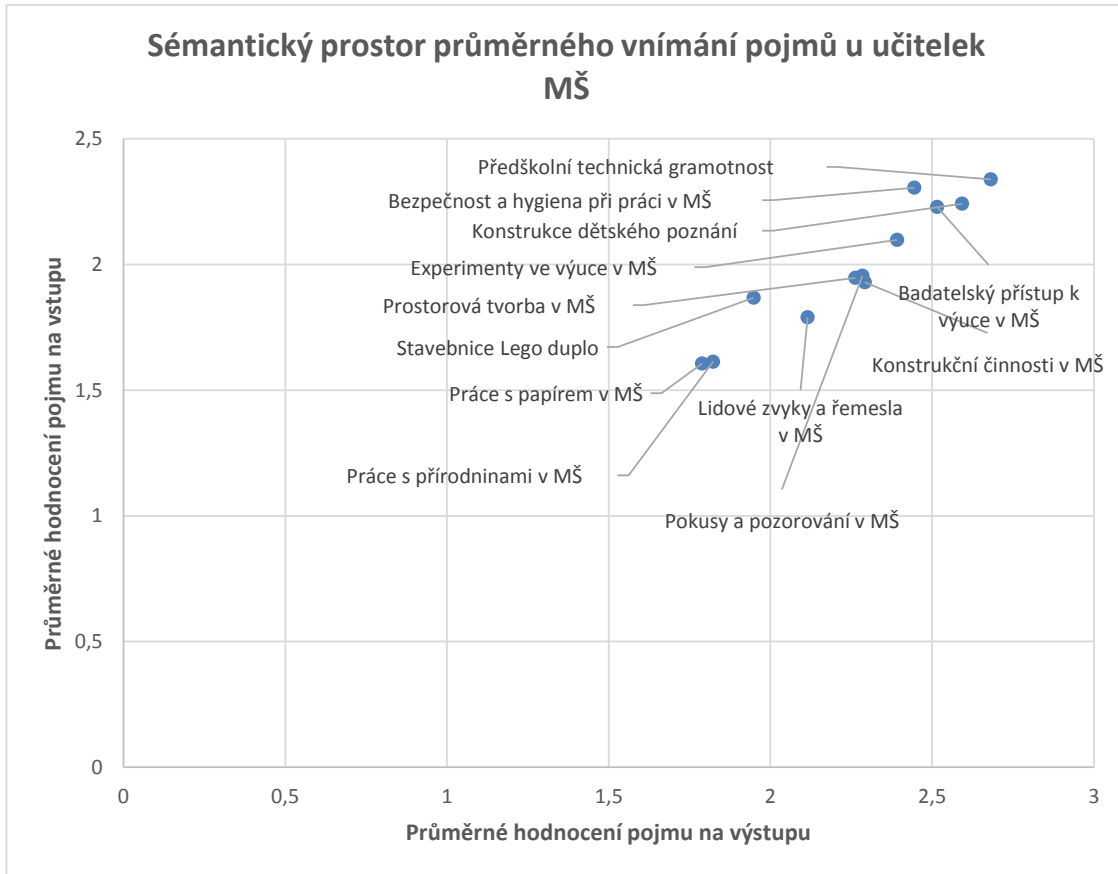

5 Shrnutí výsledků, diskuse a závěry

V závěru se snažíme především nejdříve zodpovědět výchozí otázky výzkumu. $\mathrm{Na}$ základě empirických zjištění lze charakterizovat subjektivní vnímání pojmů u respondentů na vstupu takto: největší důležitost je přikládána pojmům Práce s papírem 
v MŠ, Práce s př́rodninami v MŠ, Stavebnice Lego duplo a Lidové zvyky a řemesla v MŠ a tyto pojmy respondenti současně pokládají ve stejném pořadí za nejméně náročné na zvládnutí. Nejmenší důležitost přikládají pojmům Předškolní technická gramotnost, Konstrukce dětského poznání, Badatelský př́stup $\mathrm{k}$ výuce v MŠ a Experimenty ve výuce v MŠ a považují je za nejvíce náročné na zvládnutí, s průměrnou hodnotou výsledného skóre na vstupu do výuky.

$\mathrm{Na}$ výstupu z výuky jsme zaznamenali tuto charakteristiku subjektivního vnímání zkoumaných pojmů: vytvořená pořadí pojmů na vstupu i výstupu $\mathrm{z}$ výuky jsou velmi podobná, větši změna u faktoru hodnocení byla zaznamenána jen u pojmu Konstrukční činnosti v MŠ (vývoj je pozitivní, posun z 6 . na 4. pozici pořadí) a negativní změna byla zaznamenána u pojmu Stavebnice Lego duplo (ze 3. na 6. pozici pořadí). Ve faktoru náročnosti jsou vytvořená pořadí na vstupu a výstupu rovněž velmi podobná, pouze u pojmu Bezpečnost a hygiena př̀ práci v MŠ zaznamenáváme negativní vývoj, pokles z 10. na 12., tedy nejhorší, pozici v pořadí. Což signalizuje, že tento pojem respondenti považují na konci výuky za nejvíce náročný na zvládnutí, osvojení si.

Pojmy, které učitelky MŠ vnímají na konci výuky ve faktorech hodnocení i náročnosti významně lépe, než tomu bylo na vstupu do výuky a kde byl zaznamenán významný pozitivní vývoj a tyto pojmy jsou u respondentů plastické, zúčastněné učitelky MŠ jsou schopné je rekonstruovat: Předškolní technická gramotnost; Konstrukce dětského poznání; Badatelský př́ístup k výuce v MŠ; Experimenty ve výuce v MŠ; Konstrukční činnosti v MŠ; Prostorová tvorba v MŠ; Práce s př́rodninami v MŠ; Lidové zvyky a řemesla v MŠ, Pokusy a pozorování v MŠ́.

Pojmy, které učitelky MŠ vnímají na konci výuky ve faktorech hodnocení významně lépe, než tomu bylo na vstupu do výuky, ale ve faktoru náročnosti je vnímání na vstupu a výstupu $z$ výuky podobně, bez významného rozdílu: Bezpečnost a hygiena při práci v MŠ; Stavebnice Lego duplo.

Učitelky MŠ vnímají pojem Práce s papírem v MŠ na konci výuky ve faktoru náročnosti významně lépe, než tomu bylo na vstupu do výuky, ve faktoru hodnocení pojem vnímají na vstupu i výstupu podobně. $\mathrm{V}$ tomto faktoru je pojem rezistentní, neproběhla rekonstrukce.

V sémantickém prostoru průměrného vnímání pojmů u učitelek v MŠ, jak je zobrazeno $\mathrm{v}$ grafu 1 , lze identifikovat 3 základní shluky, 3 základní typy průměrného vnímání zkoumaných pojmů:

1. shluk tvoří pojmy Předškolní technická gramotnost, Badatelský př́istup k výuce v MŠ, Konstrukce dětského poznání a Bezpečnost a hygiena při práci v MŠ, které respondenti pokládají za průměrně důležité (ale nejméně důležité ze všech zkoumaných) a považují je ze všech za nejnáročnější, tedy $\mathrm{k}$ jejich osvojení potřebují největší, ale jen průměrnou, míru energie. Souhrnně řečeno je respondenti pokládají v souboru výzkumných pojmů za nejméně důležité, ale zároveň za velmi náročné.

2. shluk tvoří pojmy Konstrukční činnosti v MŠ, Pokusy a pozorování v MŠ a Prostorová tvorba v MŠ, které vykazují téměř identické hodnoty subjektivního vnímání. Jsou charakteristické vysokou mírou náročnosti a lepší než průměrnou mírou důležitosti. Souhrnně řečeno jsou tyto pojmy považovány za velmi náročné a rovněž velmi důležité. 3. shluk tvoří pojmy Práce s papírem v MŠ a Práce s př́rodninami v MŠ, které se vyznačují největší mírou přisouzené důležitosti a zároveň podstatně menší než průměrnou mírou předpokládané náročnosti. Souhrnně řečeno jsou tyto pojmy považovány za velmi málo náročné a zároveň ze všech zkoumaných za nejvíce důležité. 
Závěrem lze konstatovat, že subjektivní vnímání mnoha, především techničtějších pojmů, mělo u respondentů nevyhovující, zkreslenou, nerealistickou podobu. Především výzkumně zjištěná podoba nereflektuje př́liš důležitost technického vzdělávání v současné společnosti a dále důraz na pokládání základů technické gramotnosti již v předškolním věku dítěte. A je pravděpodobné, že toto neoptimální pojetí u učitelek MŠ bude zprostředkovaně spolupůsobit při vytváření předškolní technické gramotnosti u dětí a může ji př́ípadně nežádoucím způsobem ovlivnit i brzdit.

Velmi pozitivní ovšem je, že respondenti byli ochotni a schopni pojmy z velké části (celkem 9 pojmů z 12 celkem zkoumaných) zrekonstruovat, což otevírá dveře pro možnosti efektivního ovlivňování v systému dalšího vzdělávání této skupiny učitelů.

\section{Literatura}

Šmelová, E. (2013). Předškolní vzdělávání versus kutikulární reforma. In Journal of Technology and Information Education. Olomouc: Univerzita Palackého, Ročník 5, Čislo 1, s. $31-34$.

Honzíková, J. \& Sovová, P. (2013). Inovace studijního programu učitelství pro mateřské školy. In Journal of Technology and Information Education. Vol. 5, N. 3. s. 20 - 25.

Weber, K. \& Custer, R. (2005). Gender - based Preferences toward Technology Education Content, Activities and Instructional Methods. In Journal of Technology Education. Vol. 16, N. 2. [cit. 2015-07-19] Dostupné Z $\quad$ z WWW: <http://scholar.lib.vt.edu/ejournals/JTE/v16n2/pdf/weber.pdf > Honzíková, J. (2003). Vzdělávání z genderového hlediska. In Slovenské školstvi v kontexte európskej integrácie. Nitra: Ústav techhnológie vzdelávania Pf UKF. Sborník abstrakt s. 15 , sborník příspěvků CD ROM.

Chráska, M. (2003). Metody sběru a statistického vyhodnocováni dat v evaluačních pedagogických výzkumech. Praha: Votobia.

Chráska, M. (2003). Úvod do výzkumu v pedagogice. 1. vyd. Olomouc: Univerzita Palackého.

Parkinson, E. (2001). Teacher Knowledge and Understanding of Design and Technology for Children in the 3-11 Age Group: A Study Focusing on Aspects of Structures. In Journal of Technology Education. Vol. 13, N. 1. [cit. 2015-06-12] Dostupné z WWW:〈http://scholar.lib.vt.edu/ejournals/JTE/v13n1/pdf/parkinson.pdf >

Roučová, E. (2008). Problematika genderu v technickém vzdělávání. In Trendy ve vzdělávání. Olomouc: PdF UP, s. 214-218.

Roučová, E. (2013). Vnímání pojmu technická gramotnost u studentů učitelství pro primární školu a učitelů na primární škole. In Journal of Technology and Information Education. Olomouc, Univerzita Palackého, Ročník 5, Č́́slo 3, s. 35 - 43. 